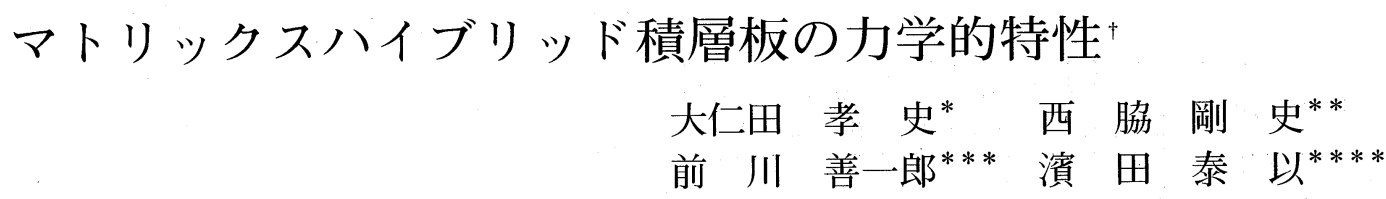

\title{
Mechanical Property of Matrix Hybrid Laminates
}

by

\author{
Takafumi OnITA ${ }^{*}$, Tsuyoshi NishiwaKI ${ }^{* *}$, Zen-ichiro MaEKaWA ${ }^{* * *}$ \\ and Hiroyuki HaMADA $* * * *$
}

\begin{abstract}
Matrix hybrid laminates are defined to be materials fabricated by the combination of two or more kinds of matrices. The wide ranges of stiffness and damping property may be produced by changing various designing parameters, the resin ratio and/or the stacking sequence. In this study, two kinds of resins are used as matrices. One is a vinyl ester resin with high stiffness and the other is unsaturated polyester resin with low stiffness. As a reinforcement, plain woven glass cloth is used. Matrix hybrid laminates with various flexible resin ratios and stacking sequences are fabricated. The static and dynamic bending properties are investigated by the three-point bending and the vibration tests, respectively. In addition, antisymmetric matrix hybrid laminates are also investigated by the above tests. For the above all experimental results, the influences of designing parameters on both static and dynamic bending properties are discussed in detail. It is confirmed that matrix hybrid laminates can have the wide ranges of stiffness and damping properties by changing the flexible resin ratio and the stacking sequence.
\end{abstract}

Key words : Matrix hybrid laminates, Flexible resin ratio, Stacking sequence, Bending property, Damping property

\section{1 緒 言}

一般の実構造物は，それぞれの用途に応じて複数の特 性が要求される場合が多い。例えば，近年の環境覀化に より代替材の開発が望まれている楽器用木材においては, 高比弾性，低減衰といった特性が要求されている. ${ }^{1) ま た, ~}$ 工業的に用いられている構造部材では, 従来の高剛性, 高強度に加えて, 近年では, 振動を抑制する設計が望ま れている。しかしながら, 単一材料による設計では, こ れらの構造部材に要求される複数の特性を併せ持たせる ことは困難である場合が多い，そのため，異なる特性を 有する材料の組み合わせにより, それらの要求特性を満 たすことができる材料設計が必要である。この設計にお いて，ハイブリッド複合材料は有用なものとなり得ると 考えられる.

ハイブリッド複合材料とは， 2 種類以上の強化材およ び母材の組み合わせにより作製された材料と定義されて いる. ${ }^{2)}$ そのため, 実構造物への適用に際し, 要求される 複数の特性を併せ持たせた材料の設計が可能であり，数 多くの研究がなされてきた。宮入ら ${ }^{3), 4)}$ は, 炭素纎維強 化プラスチック（以下，CFRP と称す）とガラス繊維強 化プラスチック（以下，GFRP と称す）を用いたサンド イッチおよびカナッぺ構造のハイブリッド複合材料の曲 げ特性についての研究を行い, ハイブリッド化により GFRP 単体よりも曲げ特性が向上することを示した．天
城ら ${ }^{5), 6)}$ は, CFRP とアラミド瀻維強化プラスチック （以下，AFRP と称す）を組み合わせたハイブリッド複合 材料を対象とし, CFRP 層と AFRP 層の体積比率扎よび 積層順序が引張拉よび曲げ特性に及ぼす影響について検 討している。.また, Kretsis)は, 強化材に炭素繊維とガ ラス繊維を用いた繊維ハイブリッド複合材料の引張, 圧 縮, 曲げ，せん断といった力学的特性に関する研究報告 例をまとめている。しかしながら, これらの研究は, 強 化材のハイブリッド化に関する報告例であり，母材に着 目したハイブリッド化に関する報告例はほとんどみられ ない. ${ }^{8), 9)}$

また，実構造物に要求される特性の一つである剛性は 理論計算により容易に求めることが可能であるが ${ }^{10}$ 動的 特性である減衰特性は, 材料自身の内部減衰や, 空気抵 抗などの外部減衰，境界条件の影響など考慮すべき点が

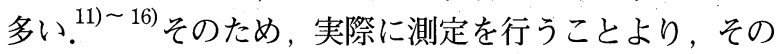
材料や構造が有している減衰特性を求める必要がある.

そこで，本研究では，強化材にガラスクロス，母材に 高剛性, 高強度を有する汎用性樹脂およびそれと化学的 構造の主骨格が同一である柔軟性樹脂を用い，これらを 様々な積層順序で組み合わせたマトリックスハイブリッ ド積層板を対象とし，曲げ試験打よび振動試験を行い， 積層順序が曲げおよび振動特性に及ぼす影響について体 系的に検討した。

$\dagger \quad$ 原稿受理 平成 12 年 9 月 7 日 $\quad$ Received Sep. 7, 2000

* 京都工芸繊維大学大学院 †606-8585 京都市左京区松ヶ崎, Graduate Student, Kyoto Inst. of Tech., Sakyo-ku, Kyoto, 606-8585

**（株アシックス７651-2271＼cjkstart神戸市西区高塚台, Asics Corp., Nishi-ku, Kobe, 651-2271

*** 正 会 員 京都工芸繊維大学先端ファイブロ科学専攻 $\bar{T}$ \% 606-8585 京都市左京区松ヶ崎, Graduate Program of Advanced Fibro Sci. in Graduate School Kyoto Inst. of Tech., Sakyo-ku, Kyoto, 606-8585

**** 京都工芸繊維大学先端ファイブロ科学専攻 †606-8585 京都市左京区松ヶ崎, Graduate Program of Advanced Fibro Sci. in Graduate School Kyoto Inst. of Tech., Sakyo-ku, Kyoto, 606-8585 


\section{2 実 験 方 法}

\section{$2 \cdot 1$ 供試材料}

強化材に平織ガラスクロス（WE18W，日東紡績(株製), 母材に沉用性樹脂としてビニルエステル樹脂（R806, 昭 和高分子(株製)，柔軟性樹脂として不飽和ポリエステル 樹脂（FK2000，昭和高分子(株)）を用いた. これらの樹脂 の引張および減衰特性を Table I に示す. Table I によ れば, 沉用性樹脂は柔軟性樹脂に比べ高剛性, 高強度を 有して扣り，それに対し，柔軟性樹脂は汎用性樹脂に比 心゙高減衰を有していることがわかる，これらの特性を有 する樹脂を母材としてマトリックスハイブリッド積層板 を作製した。成形は，ハンドレイアップ法で行い, 積層 数を 16 , 公称板厚を $3.0 \mathrm{~mm}$ とした. 対象とした積層順 序は, Fig. 1 に示すような 4 層毎にマトリックスを変化 させた $\left[\mathrm{H}_{16}\right],\left[\mathrm{F}_{16}\right],\left[\mathrm{H}_{4} \mathrm{~F}_{4}\right]_{\mathrm{s}},\left[\mathrm{F}_{4} \mathrm{H}_{4}\right]_{\mathrm{s}}$ の 4 種類とした. ここで, H および F はそれぞれ母材として汎用性および 柔軟性樹脂を用いた層を表しており，Fig. 1 では 2 層を 1 単位として積層板を描いている. なお, 䋊維体積含有 率を直接測定した結果，母材の種類に依存せず， $43 \%$ 一 定であることが確認できた。

\section{$2 \cdot 2$ 曲げ試験}

曲げ試験は，3 点曲げ試験とした。試験片形状は, 長 さ $60 \mathrm{~mm}$, 幅 $15 \mathrm{~mm}$ とし, Warp 方向を長手方向として 切り出した. 試験には，インストロン万能試験機 $(4206$ 型）を用い, 試験速度を $1.0 \mathrm{~mm} / \mathrm{min}$, 支点間距離を $48 \mathrm{~mm}$ として行った。

\section{$2 \cdot 3$ 振動試験}

試験は長さ $250 \mathrm{~mm}$, 幅 $150 \mathrm{~mm}$, 長手方向をWarp と した試験体を糸に吊した状態において，インパルスハン マーで板中央を加振し, 試験体に取り付けたセンサから 加速度応答を測定した。測定には, AD3542FFT アナラ イザー（エー・アンド・ディ社(制製）を用いた。 得られ た加振による入力情報および応答情報に高速フーリエ変 換を施し, 後者を前者で除することにより伝達関数を算 出した. 本研究では, 3 点曲げ試験と同一の主曲率を有 する Fig. 2 に示すような 1 次曲げ固有振動モードに着目 し, このモードに対応する伝達関数のピーク值から固有 振動数を求めた。 さらに, 最も振幅の大きいコーナー部 での伝達関数における 1 次曲げ固有振動数近傍に逆フー リエ変換を施すことにより，そのモードに対応した減衰 曲線を算出し, 次式より対数減衰率を求めた. ${ }^{17)}$

$$
\delta=\frac{1}{j} \ln \frac{X_{m i}}{X_{m(i+j)}}
$$

ここで, $\delta$ は対数減衰率, $X_{m i}, X_{m(i+j)}$ は, それぞれ減衰 曲線中における任意の点の振幅 $X_{m i}, X_{m i}$ を決めた点から 数えて $j$ 番目の振幅である.

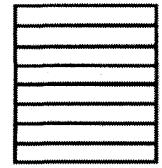

$$
\left[\mathrm{H}_{16}\right]
$$

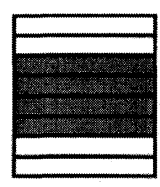

$$
\left[\mathrm{H}_{4} \mathrm{~F}_{4}\right]_{\mathrm{s}}
$$

Common resin

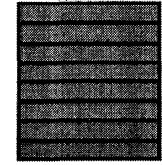

$\left[\mathrm{F}_{16}\right]$

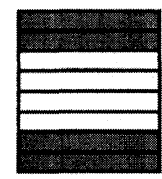

$\left[\mathrm{F}_{4} \mathrm{H}_{4}\right]_{\mathrm{s}}$
Fig. 1. Stacking sequence.

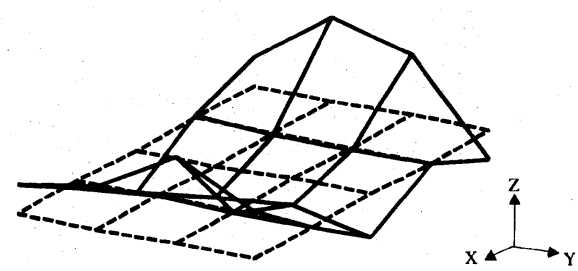

Fig. 2. Eigenvibration mode corresponded to the 1st bending frequency.

\section{$3 \cdot 1$ 曲げ試験結果}

\section{3 実 験 結 果}

曲げ試験より得られた各タイプの典型的な応力ーたわ み曲線を Fig. 3 に, 試験後の試験片断面を金属顕微鏡 により観察した断面観察写真を Fig. 4 に示す. Fig. 3，4 によれば， $\left[\mathrm{H}_{16}\right]$ における応力一たわみ曲線は，たわみの 増加と共に曲げ応力も線形的に増加していくが, 最大応 力に達する直前においてわずかな曲げ応力の低下が数回 確認され, 最大応力直後, 急激な曲げ応力の低下が確認

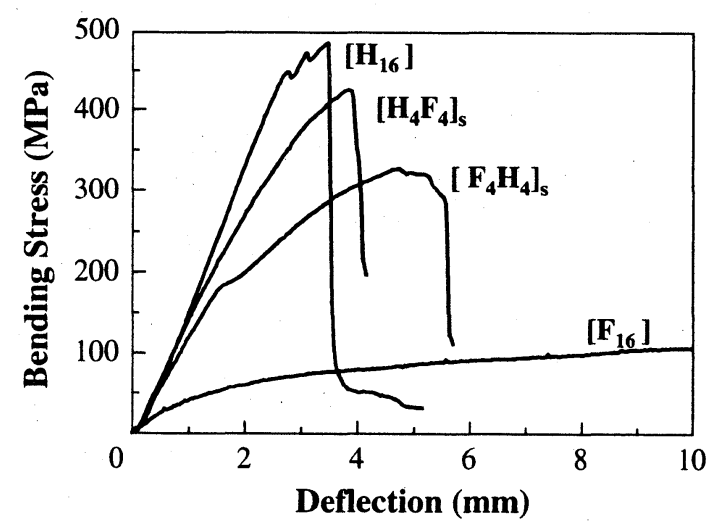

Fig. 3. Bending stress-deflection curves of matrix hybrid laminates subjected to the bending load.

Table I. Tensile and damaping properties of matrix resins.

\begin{tabular}{lcccc}
\hline Material & $\begin{array}{c}\text { Density } \\
\left(\mathbf{g} / \mathbf{c m}^{\mathbf{3}}\right)\end{array}$ & $\begin{array}{c}\text { Tensile modulus } \\
(\mathbf{G P a})\end{array}$ & $\begin{array}{c}\text { Tensile strength } \\
(\mathbf{M P a})\end{array}$ & $\begin{array}{c}\text { Logarithmic } \\
\text { decrement }\end{array}$ \\
\hline Common resin & 1.20 & 4.01 & 73.0 & 0.242 \\
Flexible resin & 1.10 & 0.37 & 0.72 & 1.002 \\
\hline
\end{tabular}



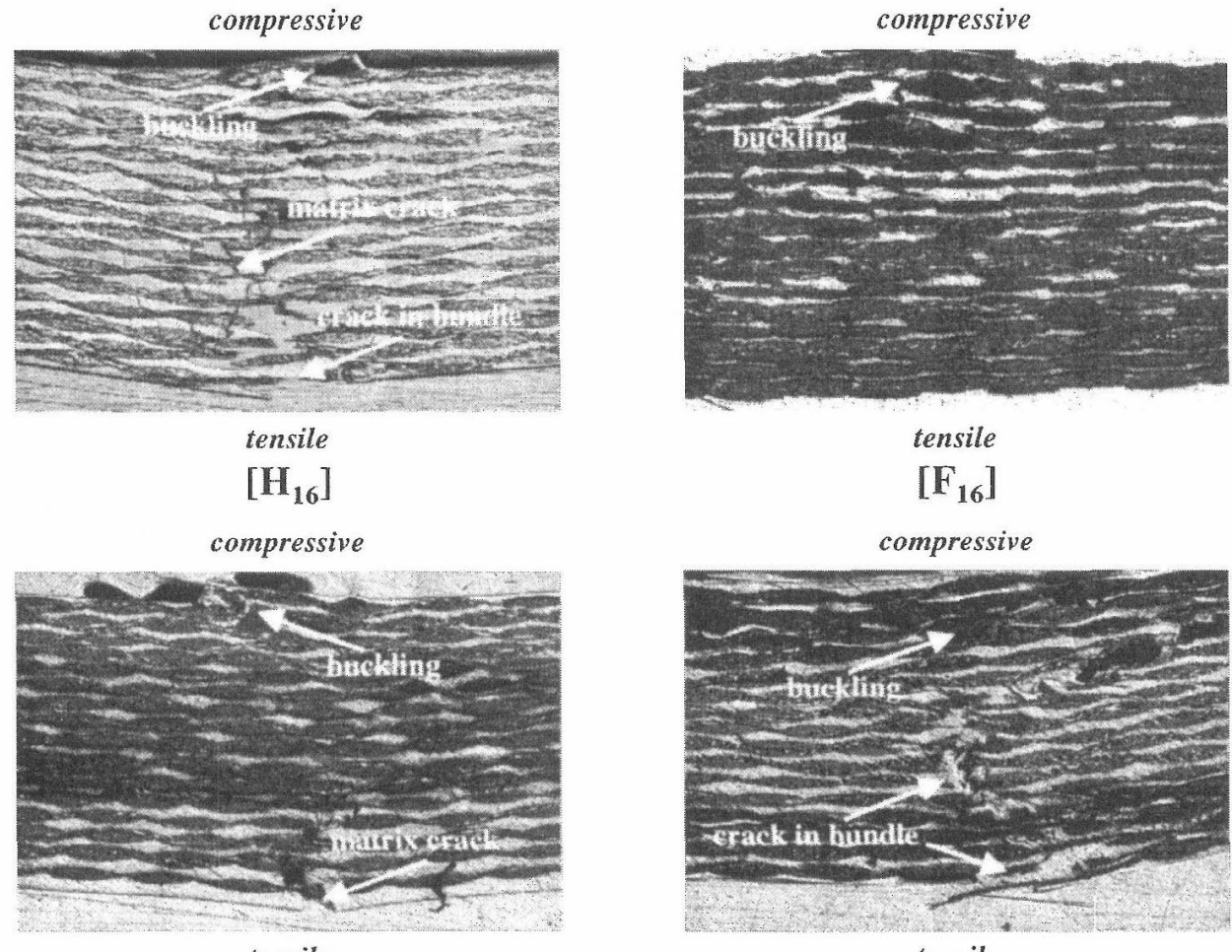

tensile

$\left[\mathrm{H}_{4} \mathbf{F}_{4}\right]_{S}$

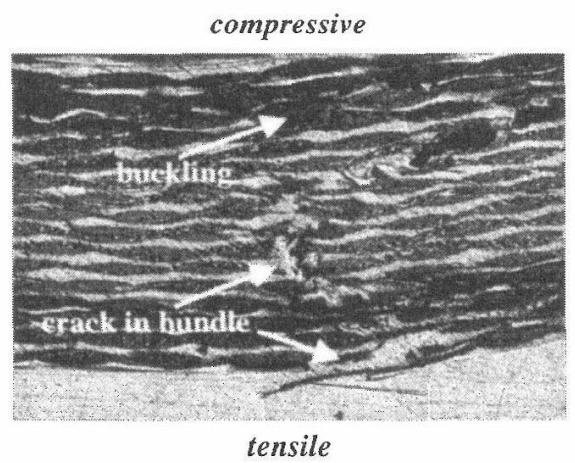

$\left[\mathrm{F}_{\mathbf{4}} \mathbf{H}_{\mathbf{4}}\right]_{\mathrm{S}}$

Fig. 4. Metallurgical microscope photographs of fracture surface in matrix hybrid laminates.

された。これを Fig. 4 の断面観察写真と対応づけた場 合, 初期の応力低下では圧縮側で座屈が起こり，その後 の低下では，引張側で繊維破断が生じたことが確認され， 破壊挙動はぜい性的であると観察された。それに詨し， $\left[\mathrm{F}_{16}\right]$ は, 他の 3 タイプと比へ, 線形的な荷重の増加はほ とんど見られず, 実験開始直後に圧縮側で座屈が発生し たが，実験後においても繊維破断は生じず，延性的な破 壊挙動を示し, 最大応力が $110 \mathrm{MPa}$ を超えることはなか った。さらに，マトリックスハイブリッド積層板として の $\left[\mathrm{H}_{4} \mathrm{~F}_{4}\right]_{\mathrm{s}} ，\left[\mathrm{~F}_{4} \mathrm{H}_{4}\right]_{\mathrm{s}}$ は， $\left[\mathrm{H}_{16}\right] ，\left[\mathrm{~F}_{16}\right]$ 両者の中間の曲げ特 性を有していると考えられ， $\left[\mathrm{H}_{4} \mathrm{~F}_{4}\right]_{\mathrm{s}}$ では，圧子点直下の 沉用性樹脂層の座屈および繊維破断が確認された。 $\left[\mathrm{F}_{4} \mathrm{H}_{4}\right]_{\mathrm{s}}$ は, 圧縮側柔軟性樹脂層のずれにより白化し，艺 の後座屈が沉用性樹脂層に進展し, 引張側柔軟性樹脂層 の繊維が破断した。また，いずれのタイプも非線形的な 破壊挙動を示すことが観察された。次に，応力一たわみ 曲線から得られた曲げ弾性率および曲げ強度をTable II に示す. Table IIによれば, 曲げ弾性率, 曲げ強度共に,
$\left[\mathrm{F}_{16}\right],\left[\mathrm{F}_{4} \mathrm{H}_{4}\right]_{\mathrm{s}},\left[\mathrm{H}_{4} \mathrm{~F}_{4}\right]_{\mathrm{s}},\left[\mathrm{H}_{16}\right]$ の順に高くなることがわ かる、これは，最も大きな応力を受ける最外層に風性の 高い沉用性樹脂層を配したことに起因している。また， $\left[\mathrm{H}_{4} \mathrm{~F}_{4}\right]_{\mathrm{s}}$ を $\left[\mathrm{H}_{16}\right]$ と比較した場合, 曲げ弾性率, 曲げ強度 は低下し，破断たわみは増加する。逆に， $\left[\mathrm{F}_{4} \mathrm{H}_{4}\right]_{\mathrm{s}}$ を $\left[\mathrm{F}_{16}\right]$ と比較した場合, 曲げ弾性率, 曲げ強度は増加す るが，破断たわみは低下することが確認された。さらに， $\left[\mathrm{H}_{16}\right]$ および $\left[\mathrm{F}_{16}\right]$ の曲げ弾性率をもとに, 古典積層理 論 18$)$, 19)により $\left[\mathrm{H}_{4} \mathrm{~F}_{4}\right]_{\mathrm{s}}$ の曲げ弾性率予測を行なった。先 の結果, $\left[\mathrm{H}_{4} \mathrm{~F}_{4}\right]_{\mathrm{s}}$ の等価曲げ弾性率は $20.1 \mathrm{GPa}$ であり， 実験值との間に差が見られた。これは，積層板中に樹脂 層間が存在することによって，理論と比較した場合，実 験で得られた曲げ弾性率が低下したものと考えられる。 このことから，均質材をもとにした古典積層理論の適用 は困難であると思われる。

\section{$3 \cdot 2$ 振動試験結果}

振動試験から得られた 1 次曲げ固有振動数および対数 減衰率を Table III示す. Table IIIによれば, 1 次曲げ

Table II. Bending modulus and strength obtained by bending test.

\begin{tabular}{ccc}
\hline Type & $\begin{array}{c}\text { Bending modulus } \\
(\mathbf{G P a})\end{array}$ & $\begin{array}{c}\text { Bending strength } \\
(\mathbf{M P a})\end{array}$ \\
\hline$\left[\mathbf{H}_{16}\right]$ & 22.0 & 460 \\
{$\left[\mathbf{F}_{16}\right]$} & 6.96 & 110 \\
{$\left[\mathbf{H}_{4} \mathbf{F}_{4}\right]_{\mathbf{s}}$} & 17.3 & 423 \\
{$\left[\mathbf{F}_{4} \mathbf{H}_{4}\right]_{\mathbf{s}}$} & 15.2 & 331 \\
\hline
\end{tabular}


Table III. 1st bending frequency and logarithmic decrement obtained by vibration test.

\begin{tabular}{ccc}
\hline Type & $\begin{array}{c}\text { 1st bending } \\
\text { frequency }(\mathbf{H z})\end{array}$ & $\begin{array}{c}\text { Logarithmic } \\
\text { decrement }\end{array}$ \\
\hline$\left[\mathbf{H}_{\mathbf{1 6}}\right]$ & 181.1 & 0.077 \\
{$\left[\mathbf{F}_{\mathbf{1 6}}\right]$} & 163.4 & 0.199 \\
{$\left[\mathbf{H}_{\mathbf{4}} \mathbf{F}_{\mathbf{4}}\right]_{\mathbf{s}}$} & 169.9 & 0.095 \\
{$\left[\mathbf{F}_{\mathbf{4}} \mathbf{H}_{\mathbf{4}}\right]_{\mathbf{s}}$} & 164.9 & 0.143 \\
\hline
\end{tabular}

固有振動数は，曲げ試験結果と同様， $\left[\mathrm{F}_{16}\right],\left[\mathrm{F}_{4} \mathrm{H}_{4}\right]_{\mathrm{s}}$, $\left[\mathrm{H}_{4} \mathrm{~F}_{4}\right]_{\mathrm{s}} ，\left[\mathrm{H}_{16}\right]$ の順に高くなることがわかる。これは， 曲げ剛性が大きくなるに従い，長手方向に主曲率を有す る 1 次曲げ固有振動モードが励起されにくくなったため

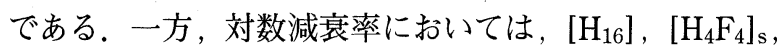
$\left[\mathrm{F}_{4} \mathrm{H}_{4}\right]_{\mathrm{s}},\left[\mathrm{F}_{16}\right]$ の順に大きくなることがわかった。これ は, 最も変形の大きくなる最外層に変形の起こりやすい 柔軟性樹脂層を配したことに起因している。さらに， $\left[\mathrm{H}_{4} \mathrm{~F}_{4}\right]_{\mathrm{s}}$ と $\left[\mathrm{F}_{4} \mathrm{H}_{4}\right]_{\mathrm{s}}$ の比較より, 通常, 曲げモードが励起 された場合においては, 中立軸近傍での面外せん断変形 の影響により対数減衰率が増加するが ${ }^{20)}$ マトリックスハ イブリッド積層板の場合, 最外層に柔軟性樹脂層を配し た方がより対数減衰率の増加において効果的であること が明らかとなった．以上の結果より，積層順序を変化さ せることにより，幅広い剛性と減衰特性を有する材料の 設計が可能であることが示された。

\section{$4 \cdot 1$ 非対称積層板}

\section{4 考察}

先に述べた中立面に対して対称である対称積層板では， 引張, 曲げなどのカップリングが生じない.しいしなが ら, 実構造物においては, しばしば要求される特性によ って，故意にカップリングを生じる非対称積層板による

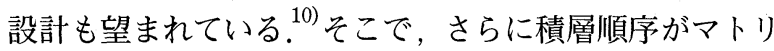
ックスハイブリッド積層板の曲げおよび振動特性に及ぼ
す影響についてより詳細に検討するため，Fig. 5 に示す 非対称積層板を作製し，同様の試験を行った．

$4 \cdot 1 \cdot 1$ 非対称積層板の曲げ特性 曲げ試験から得 られた曲げ弾性率および曲げ強度を Table IVに示す。柔 軟性樹脂の割合が同じタイプで比較した場合，曲げ弾性 率, 曲げ強度共に, $\left[\mathrm{H}_{8} \mathrm{~F}_{4} \mathrm{H}_{4}\right]$ の方が $\left[\mathrm{H}_{12} \mathrm{~F}_{4}\right]$ より， $\left[\mathrm{H}_{4} \mathrm{~F}_{4} \mathrm{H}_{4} \mathrm{~F}_{4}\right]$ の方が $\left[\mathrm{H}_{8} \mathrm{~F}_{8}\right]$ より, $\left[\mathrm{H}_{4} \mathrm{~F}_{12}\right]$ の方が $\left[\mathrm{F}_{4} \mathrm{H}_{4} \mathrm{~F}_{8}\right]$ より高くなっていることがわかる。これは，最も大きな 応力を受ける最外層に剛性の高い汎用性樹脂層を配した, もしくは, 沉用性樹脂層の割合が大きいためであると考 えられる。

$4 \cdot 1 \cdot 2$ 非対称積層板の振動特性 振動試験から得 られた 1 次曲げ固有振動数および対数減衰率を Table V に示す．柔軟性樹脂の割合が同じタイプで比較した場合， 1 次曲げ固有振動数は, 曲げ試験結果と同様, $\left[\mathrm{H}_{8} \mathrm{~F}_{4} \mathrm{H}_{4}\right]$ の方が $\left[\mathrm{H}_{12} \mathrm{~F}_{4}\right]$ より， $\left[\mathrm{H}_{4} \mathrm{~F}_{12}\right]$ の方が $\left[\mathrm{F}_{4} \mathrm{H}_{4} \mathrm{~F}_{8}\right]$ より高い 值を示している。これは, 最外層に剛性の高い汎用性樹 脂層を配したことにより構造物全体の曲げ剛性が増加し たためである。一方，対数減衰率は， $\left[\mathrm{H}_{12} \mathrm{~F}_{4}\right]$ の方が $\left[\mathrm{H}_{8} \mathrm{~F}_{4} \mathrm{H}_{4}\right]$ より，[$\left[\mathrm{F}_{4} \mathrm{H}_{4} \mathrm{~F}_{8}\right]$ の方が $\left[\mathrm{H}_{4} \mathrm{~F}_{12}\right]$ より大きくなっ ている。これは, 最も変形の大きくなる最外層に, 高減 衰な柔軟性樹脂を母材とした層を配したことに起因して いると考えられる。 $\left[\mathrm{H}_{8} \mathrm{~F}_{8}\right]$ と $\left[\mathrm{H}_{4} \mathrm{~F}_{4} \mathrm{H}_{4} \mathrm{~F}_{4}\right]$ においては, 1 次曲げ固有振動数, 対数減衰率共に差は見られなかった。
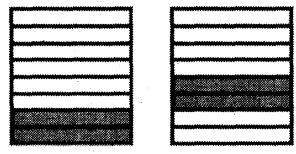

$\left[\mathbf{H}_{12} \mathbf{F}_{4}\right]$

$\left[\mathrm{H}_{8} \mathrm{~F}_{4} \mathrm{H}_{4}\right]$
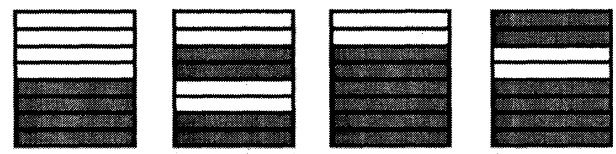

$\left[\mathrm{H}_{8} \mathrm{~F}_{8}\right]$

$\left[\mathrm{H}_{4} \mathrm{~F}_{4} \mathrm{H}_{4} \mathrm{~F}_{4}\right] \quad\left[\mathrm{H}_{4} \mathrm{~F}_{12}\right]$

$\left[\mathbf{F}_{4} \mathbf{H}_{4} \mathbf{F}_{8}\right]$

Fig. 5. Stacking sequences of antisymmetric matrix hybrid laminates.

Table IV . Bending modulus and strength of antisymmetric laminates.

\begin{tabular}{llllllll}
\hline & {$\left[\mathrm{H}_{12} \mathrm{~F}_{4}\right]$} & {$\left[\mathrm{H}_{8} \mathrm{~F}_{4} \mathrm{H}_{4}\right]$} & {$\left[\mathrm{H}_{8} \mathrm{~F}_{8}\right]$} & {$\left[\mathrm{H}_{4} \mathrm{~F}_{4} \mathrm{H}_{4} \mathrm{~F}_{4}\right]$} & {$\left[\mathrm{H}_{4} \mathrm{~F}_{12}\right]$} & {$\left[\mathrm{F}_{4} \mathrm{H}_{4} \mathrm{~F}_{8}\right]$} \\
\hline $\begin{array}{c}\text { Bype } \\
\begin{array}{c}\text { Bending modulus } \\
(\mathbf{G P a})\end{array}\end{array}$ & 15.4 & 20.7 & 9.75 & 13.5 & 6.81 & 6.48 \\
\hline $\begin{array}{c}\text { Bending strength } \\
(\mathbf{M P a})\end{array}$ & 391 & 461 & 288 & 390 & 160 & 143 \\
\hline
\end{tabular}


Table V. 1st bending frequency and logarithmic decrement of antisymmetric laminates.

\begin{tabular}{cccccccc}
\hline & {$\left[\mathrm{H}_{12} \mathrm{~F}_{4}\right]$} & {$\left[\mathrm{H}_{8} \mathrm{~F}_{4} \mathrm{H}_{4}\right]$} & {$\left[\mathrm{H}_{8} \mathrm{~F}_{8}\right]$} & {$\left[\mathrm{H}_{4} \mathrm{~F}_{4} \mathrm{H}_{4} \mathrm{~F}_{4}\right]$} & {$\left[\mathrm{H}_{4} \mathrm{~F}_{12}\right]$} & {$\left[\mathrm{F}_{4} \mathrm{H}_{4} \mathrm{~F}_{8}\right]$} \\
\hline $\begin{array}{c}\text { Ist bending } \\
\text { frequency }(\mathrm{Hz})\end{array}$ & 160.8 & 172.2 & 154.6 & 154.9 & 155.1 & 149.6 \\
\hline $\begin{array}{c}\text { Logarithmic } \\
\text { decrement }\end{array}$ & 0.121 & 0.087 & 0.142 & 0.143 & 0.170 & 0.180 \\
\hline
\end{tabular}

\section{$4 \cdot 2$ 曲げ特性と減衰特性の関係}

マトリックスハイブリッド積層板の積層順序が静的曲 げ特性と減衰特性に及ぼす影響を議論するため，横軸に 3 点曲げ試験より得られた曲げ剛性, 縦軸に振動試験か ら得られた減衰特性の指標となる対数減衰率をとったグ ラフを Fig. 6 に示す. 図中の結果は, 先の対称積層板扔 よび非対称積層板に加え，柔軟性樹脂比率を $25 \%$ 一定と し積層順序を変化させた積層板の曲げおよび振動試験結 果も併せて示している。また，図中の a-i は，柔軟性樹 脂比率 $25 \%$ の積層板, $\left[\mathrm{H}_{6} \mathrm{~F}_{2}\right]_{\mathrm{s}},\left[\mathrm{H}_{6} \mathrm{~F}_{2} \mathrm{H}_{2} \mathrm{~F}_{2} \mathrm{H}_{4}\right]$, $\left[\mathrm{H}_{6} \mathrm{~F}_{2} \mathrm{H}_{4} \mathrm{~F}_{2} \mathrm{H}_{2}\right],\left[\mathrm{H}_{6} \mathrm{~F}_{2} \mathrm{H}_{6} \mathrm{~F}_{2}\right],\left[\mathrm{H}_{8} \mathrm{~F}_{4} \mathrm{H}_{4}\right],\left[\mathrm{H}_{8} \mathrm{~F}_{2} \mathrm{H}_{2} \mathrm{~F}_{2} \mathrm{H}_{2}\right]$, $\left[\mathrm{H}_{8} \mathrm{~F}_{2} \mathrm{H}_{4} \mathrm{~F}_{2}\right],\left[\mathrm{H}_{12} \mathrm{~F}_{4}\right],\left[\mathrm{F}_{2} \mathrm{H}_{6}\right]_{\mathrm{s}}, \mathrm{j}-\mathrm{m}$ は, 柔軟性樹脂比率 $50 \%$ の積層板, $\left[\mathrm{H}_{4} \mathrm{H}_{4}\right]_{\mathrm{s}},\left[\mathrm{F}_{4} \mathrm{H}_{4}\right]_{\mathrm{s}},\left[\mathrm{H}_{8} \mathrm{~F}_{8}\right],\left[\mathrm{H}_{4} \mathrm{~F}_{4} \mathrm{H}_{4} \mathrm{~F}_{4}\right]$, $\mathrm{n}$ および 。は，柔軟性樹脂比率 $75 \%$ の積層板, $\left[\mathrm{H}_{4} \mathrm{~F}_{12}\right]$, $\left[\mathrm{F}_{4} \mathrm{H}_{4} \mathrm{~F}_{8}\right]$ をそれぞれ示している．Fig. 6 によれば，柔軟 性樹脂比率 $25 \%$ に打汁る i , g , h と，50\%に打ける $\mathrm{k}$, $\mathrm{m}, 1$ において，同等の対数减衰率を有しつつ，曲け剛性 の増加が確認された。 また, 柔軟性樹脂比率 $25 \%$ の f, c, $\mathrm{a}, \mathrm{e}$ を比較した場合，同等の曲け浻性を有しつつ，対数 減衰率のみ増加させ得ることが確認された。さらに，柔 軟性樹脂比率 $25 \%$ の $\mathrm{f}, \mathrm{c}, \mathrm{b}$ に打いて, 同一の樹脂比率
でありながら，曲げ岡性，対数減衰率共に増加し得るこ とが確認できた，通常，均質材において曲げ岡性と対数 減衰率は負の相関を有していることが多いが，本研究で 提案したマトリックスハイブリッド積層板では，相反す るといえる 2 つの特性のうち 1 つを維持したまま他方を 変化させ得るような設計が可能である。

先と同様に，横軸に曲げ強度，縦軸に対数減衰率をと ったグラフを Fig. 7 に示す. Fig. 7 によれば，柔軟性樹

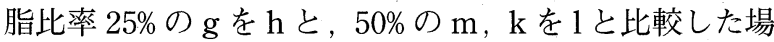
合, 同等の対数减衰率を有しつつ, 曲げ強度が増加する. また，柔軟性樹脂比率 $25 \%$ の d, f, c を e と比較した場 合, 曲げ強度だけでなく，対数減衰率も増加する，さら に，柔軟性樹脂比率 $25 \%$ の b c c を全て沉用性樹脂であ るムと比較した場合，柔軟性樹脂層を挿入することによ って，対数減衰率だけでなく曲げ強度も増加することが 確認された。以上の結果から，同じ柔軟性樹脂比率の積 層板において，柔軟性樹脂層の位置を変化させることに より，様々な曲げ強度，対数减衰率の設計が可能であり， さらに，柔軟性樹脂層を挿入することにより，対数減衰 率だけでなく，曲げ強度も向上させることが可能である ことが確認できた
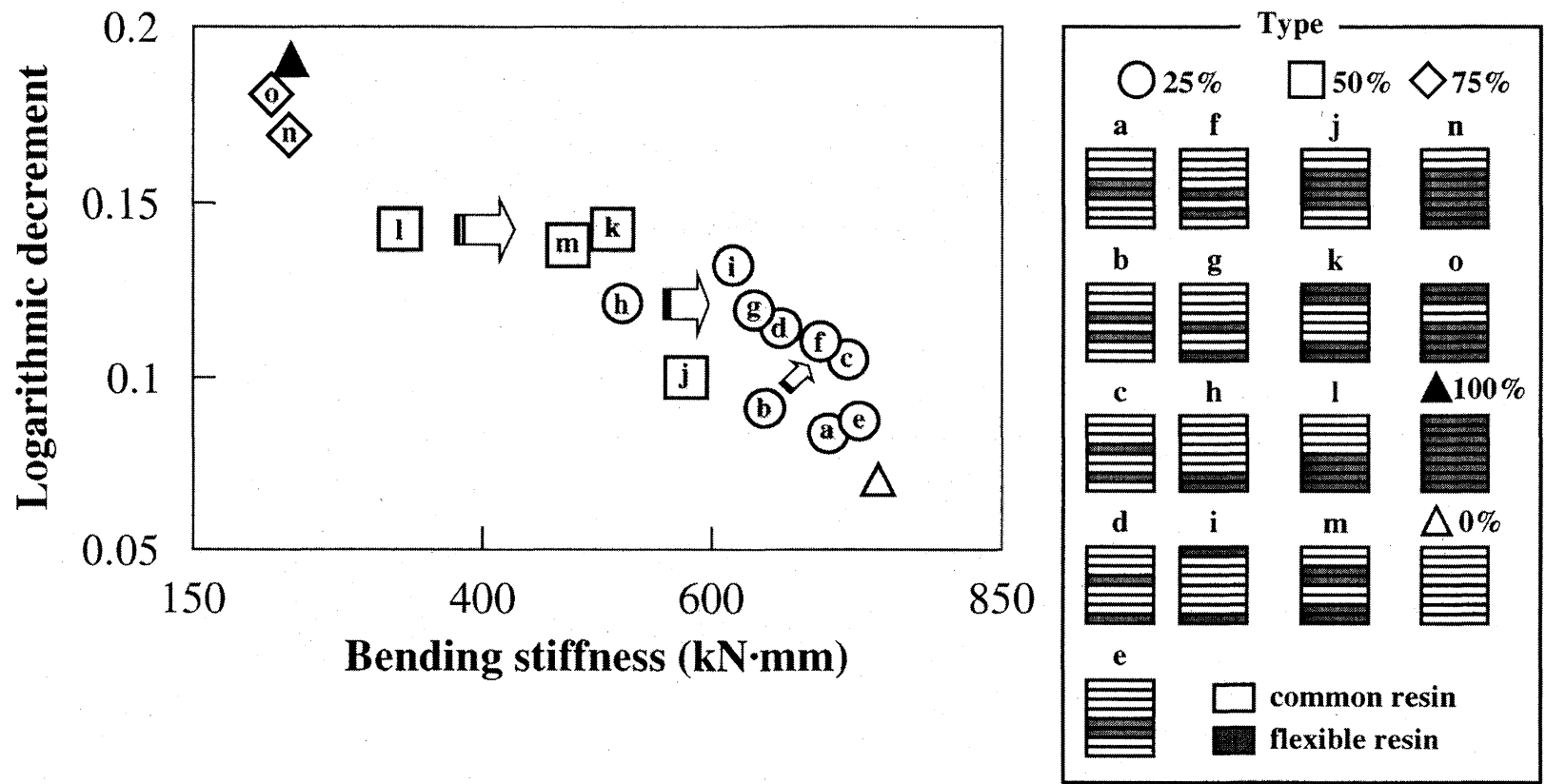

Fig. 6. Logarithmic decrement plotted against bending stiffness for matrix hybrid laminates. 

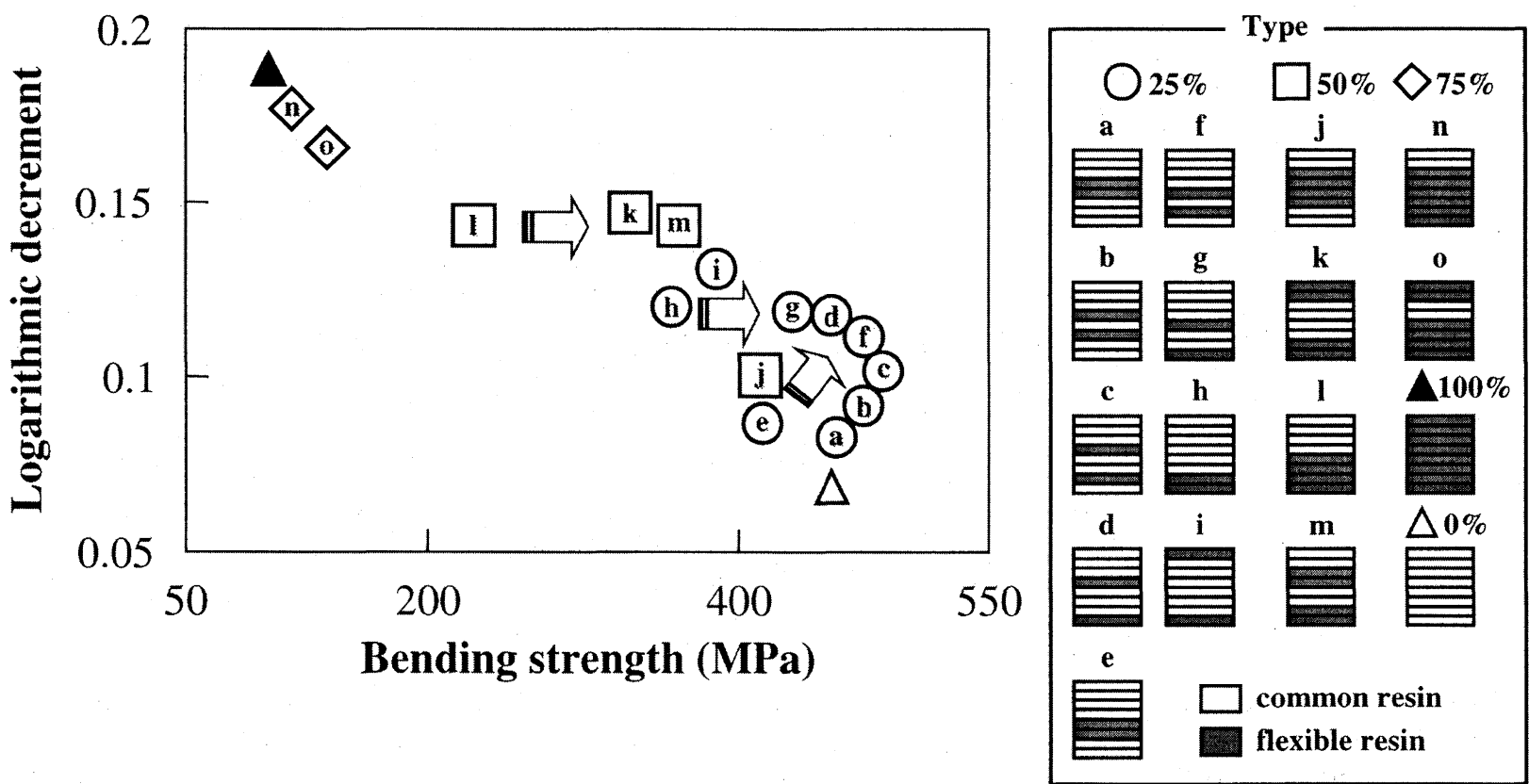

Fig. 7. Logarithmic decrement plotted against bending strength for matrix hybrid laminates.

\section{5 結言}

本研究では, 高剛性, 高強度を有する沉用性樹脂と高 減衰を有する柔軟性樹脂を母材としたマトリックスハイ ブリッド積層板を作製し，曲げ試験および振動試験を行 った結果，以下のことが明らかになった。

（1）柔軟性樹脂比率，積層順序を変化させることによ り，幅広い静的曲げ特性と減衰特性の設計が可能である。

（2）マトリックスハイブリッド積層板の樹脂比率，積 層順序を変化させることによって, 様々な静的曲げ特性 および減衰特性を併せ持ち, 実構造物に要求される特性 に応じた材料の設計が可能であることが示された。

\section{参 考 文 献}

1) 片岡明雄, 小野晃明, 木材学会誌，22，436 (1976).

2）植村益次, 福田 博, “八イブリッド䋐維強化複合材料”, p.1 (1986) シーエムシー。

3）宮入裕夫, 永井正洋, 村松篤良, 日本複合材料学会誌, 2 , 88 (1976)

4) 永井正洋, 宮入裕夫, 村松篤良, 日本複合材料学会誌, 3 , 104 (1977).

5) 天城滋夫, 宮野 靖, 日本複合材料学会誌, 11，62 (1985).
6) 天城滋夫, 和嶋元世, 宮野 靖, 日本複合材料学会誌, 12, 171 (1986).

7) G. Kretsis, Composites, 18, 13 (1987).

8 ) T. A. Collings, Composites, 22, 369 (1991).

9) C. J. Wang, B. Z. Jang, J. Panus and B. T. Valaire, Journal of Reinforced Plastics and Composites, 10, 356 (1991).

10) R. M. Jones, "Mechanics of Composite Materials", p.147, (1975) Hemisphere Publishing Corporation.

11) R. Chandra, S. P. Singh and K. Gupta, Composite Structures, 46, 41 (1999).

12) M. Coni, B. Benchekchu and R. G. White, Composite Strucures, 35, 207 (1996).

13）岩䀆卓三，日本機械学会論文集，C-59，2921（1993）.

14) R. M. Crane and J. W. Gillespie, Jr, Composite Science and Technology, 40, 355 (1991).

15) A. A. Elhamid Hamada, Composite Structures, 32,33 (1995).

16) R. Rikards, Composite Structures, 24, 193 (1993).

17) S. Timoshenko, “新版工業振動学”, p.56（1977）コロナ 出版.

18）宮入裕夫，村松篤良，永井正洋，材料， 24，144（1975）.

19）宮入裕夫，永井正洋，村松篤良，材料，28，1187 (1979).

20）丸岡邦明, 工業材料, 42, 10, 24 (1994). 